\title{
Caricature of Ethics in the Poetry of Kabir
}

\author{
Aditya Angiras \\ Department of VVBIS\& IS (PU) Sadhu Ashram, Hoshiarpur, India
}

Copyright $\subseteq 2018$ by authors, all rights reserved. Authors agree that this article remains permanently open access under the terms of the Creative Commons Attribution License 4.0 International License

\begin{abstract}
ETHICS, precisely, is a rational enquiry in to the standards of righteous and wrongful actions to decide which are superior and inferior, in relation to the character and conduct. These are minimum standards for righteous living which are accepted by a class of individuals with higher understanding and are socially approved by everyone. In the context of Kabir, this kind of study falls under the category of "conduct" which was practiced by him under the supervision and guidance of a "Trained Guru" who is known to be a moralist and is a competent authority to guide his disciple on the righteous path of life by making him aware about the difference between vices and virtues. In other words, the trained disciple is the moral perfectionist who is not deluded by any of the vices. Kabir, one of the prominent medieval versifiers has been making clarion calls about carrying out the conduct in a righteous way. He, himself, not only conducts himself on the righteous and uncritical path of life but also talks uniquely about the virtues of life undauntedly in vivid colors which are to be followed by each one in his/her life. An attempt has been made through this paper to see and analyze those moral principles that were propagated by Kabir through his poetry.
\end{abstract}

Keywords Ethics, Hindi Poetry, Medieval Indian Poetry, Humanism, Bona Fides, Learning from Past Errors, History of Hindi Literature

\section{Introduction}

Ethics, sometimes, known as moral philosophy, is a branch of philosophy that involves systematizing, defending and recommending concepts of right and wrong conduct, often addressing disputes of moral diversity [1].

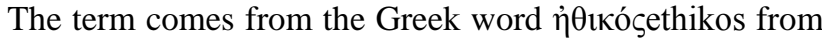
$\tilde{\eta} \theta$ ogethos, which means "custom, habit"[2]. The super field within philosophy known as axiology includes both ethics and aesthetics and is unified by each sub-branch's concern with value[3].Philosophy investigates what is the best way for humans to live, and what kinds of actions are right or wrong in particular circumstances. In other words, it may be said that Ethics is a mental faculty which enables a man to probe deep, distinguish and choose worthy from worthy and unworthy deeds[4].

It will be not out of point to state here that according to Hinduism, the entire human life has four objectives viz. Dharma (Religious acts), Artha (Money matter), Kama (Desire) \& Moksha (emancipation). The first three are, whereas, related to immanent world where as the fourth objective i.e. Moksha (emancipation) is associated with transcendental world. And each of these objectives is linked with our action force. The first three are related to the worldliness and the fourth one is related to psychic world which steers the human being in to action to attain the desired objectives. Using socially approved means to attain the objective is called the ethics.

The word "Ethics" literary means "Moral principles that control or influence the behavior of a person or a system of moral principles or rules of behavior" [5]. Dino Lobaton states that "standard definitions of ethics have typically included such phrases as 'the science of the ideal human character' [6] or 'the science of moral duty' [7].Richard William Paul and Linda Elder define ethics as "a set of concepts and principles that guide us in determining what behavior helps or harms sentient creatures"[8]. The Cambridge Dictionary of Philosophy defines states that the word ethics is "commonly used interchangeably with 'morality' ... and sometimes it is used more narrowly to mean the moral principles of a particular tradition, group or individual[9].Paul and Elder state that most people confuse ethics with behavior in accordance with social conventions, religious beliefs and the law and don't treat ethics as a stand-alone concept[10].Meaning from the above-said assertion can be drawn that

1. That these principles are normative in nature.

2. That these principles are directly related to action/deeds of a man.

3. That these principles and have a great deal of influence on human behavior and it effect the behavior of a person in positive sense

4. That these principles are the guiding light or the guiding lines which enables a man to

- Differentiate/draw a line in between worthy and unworthy deeds. 
- Decide and choose the righteousness with the willingness to improve one's conduct in positive sense.

We, in English language, find a parallel expression for word ethics that is Morality. It must be said that both of words, although commonly understood and used in same sense, but have a slightly different connotation. Morality, it may be said, is borrowed from where as social environment whereas ethics is the innate quality driven by intuitive insight. It will be justified to say that ethics inspires us to perform the worthy deed.

\section{Kabir and His Times}

As per Scholars of Indian history and languages, the history of Hindi language and literature twitches approximately from the 10th century $\mathrm{AD}$ when the different Central Asian tribes invaded Indian Territories for its riches with an idea of expansion of their respective political territories and this period is considered to be the period of turmoil in History of Indian Subcontinent. Some of the prominent persons of Hindi literature like Acharya Ram Chandra Shukla and Acharya Hazari Prasad Dwevdi opine on this issue that the conjunction period this turmoil between the Central Asian Tribes and native Indian creeds gave birth to a new language. The language thus born out due to the interaction between the different cultures of Central Asian Tribes and Indic origin was termed as Hindi. It was a mixture of Sanskrit, Pali, Prakrit, Arabian and old Persian languages. It is evident that the advent of Islam in India was in two forms Ist being in the form of Sufism which was more polite and submissive in nature and IInd form being in the form of ardent and inflexible religion or we might say the stiff one. This period of cultural clash between people of Indic origin and central Asian tribes goes up to mid-14thcentury. References have been made to certain events like veiling tradition in became prevalent in Hinduism and rituals of austerities being made in the name of Pir, Khwaja, Chisty etc. in Central Asian tribes had started during this time. This period is followed by the Bhaktikal (period of entreaty and devotion to Power Supreme or period of oblation to the power Supreme). This period of devout period reigns from mid-14th century to mid-17th century in the history of Hindi literature as per history of Hindi literature. As said earlier, this cultural mixing gave rise to different worshipping techniques which includes Sufism from the central Asian tribes and Saint from the Hinduism. Saints, on the basis and types of their oblation made to the Power supreme are characterized in to two parts i.e. one who were worshippers of the formless/shapeless power Supreme and the second being those who worshipped the Power Supreme in a definite shape or form. The second ones are further categorized in the two sects name saints pertaining to Krishna and second type of poets were those who considered the Lord Rama as the ultimate adobe of their oblation. We should also keep this fact in our mind that there were other indigenous tribes like Siddha, yogis, Nath traditions were also deep rooted in the Indian psyche that were closely related to Muni Patanjali. The birth of Kabir is associated with such a period of cultural turmoil of India. Although there are different version about the birth details and according to some Anecdotes the Kabir was left by his mother on the banks of a water reservoir and was fostered by Mohammadam Couple named Neeru and Neema, who were weaver by profession, Yet the year of birth of Kabir is fixed around 1399AD and $1528 \mathrm{AD}$ approximately. With a wild guess, we can state that the forefathers of Kabir belonged to a corrupted class who changed their religion from Nath and sidh to Muslims due to some reason or the other. Kabir, as he himself states, had never been to any kind of school "Masi kagad chhuyo nahin, Kalam gahyo nahin haath" but yet the couplets and other form of poetry was orated by him verbally which was later jotted down by his followers in four parts .i.e.1. Koot Vani, 2. Taksaar, 3. Mool Gyan and 4. Beejak Vaani. He got initiated at Varanasi (Banaras) by his spiritual Master Ramanand. We can understand that Kabir is saint devout of the formless Power Supreme once we read his poetry and is skeptic about the concept of incarnation, racism based on caste color or creed. Poetry of Kabir has been collected by Rabindranath Tagore, supported by Evelin Underhill in a book form titled One Hundred Poems of Kabir (2005) and by Robert Bly (2007) titled Kabir: Ecstatic Poems.

Although, it may be said that the cultural impact on the various factions gradually became evident yet, it may said that, somehow, there was an element of mutual mistrust, fanaticism; religious rigidity etc. in of various Indian factions like Sidh Cult, Nath Cult and their counterpart from the Central Asia. All of these factions were drawing their lines in the name of ardent religious practices that were against the higher humane laws and values. Kabir, through his poetry, not only tried to sort out the differences being made in the name of Power supreme by controlling the senses but also yielded valuable teachings through his oration as to him, human being was the supreme. In this context, the expressions used by Kabir namely Hindu and turuk (Turk or Muslim) have deeper connotations. The word Hindu implies to those who believe in Veda, or Brahmin or other indigenous cult practice followers and Turuk implies to those invaders, who had settled in India by time of birth of Kabir and had been carrying out the religious practices of Prophet Mohamad. It include shiya and Sunni cult practices. The teaching have been influenced the ancient Indian Veda, Upanishads, Sidh, Nath Cults from the Hindu faction and collections of Muslim orators like Murshid, Mohammad Sharif, Ali Raja etc from the Muslim faction. His teaching still hold their position in a positive sense in the present set up of Indian society since Kabir present the ideal ground of thought process for the entire humanity at large. 


\section{Ethics of Kabir Explained}

It goes without saying that the Indian civilization is the oldest one in the world and, presently, is a living tradition. The Indian civilization, as is believed, dawns before the birth of Christ. The historians believe that the present Indian living tradition augmented in 25000 BC. The language used for communication in this period was Sanskrit. The earliest Indian literature took the form of the canonical Hindu sacred writings before the birth of Christ that were known as The Vedas. To the Veda were added prose commentaries such as the Brahmans, The Upanishads Srimad Bhagavad Gita and Patanjali Yoga Sutra. The production of Sanskrit literature extended from about 1400 bc to ad1St Century and reached its height of development in the 7th to1st centuries BC. We find different schools of philosophy during these times viz. the Jnana philosophy of Upanishads Sankhya philosophy, Charvaak philosophy, Jain Philosophy, Buddhist philosophy, Yoga philosophy etc.. It must be admitted that the impact of these philosophies was so enormous that whole of the Indian subcontinent got sectarian division on the basis of these philosophical sects being propagated by the the philosophical schools.

Due to the then prevailing sociological conditions of around 2nd to 4th century, Sanskrit language was identified and associated with the higher classes of Hindu Hierarchical domain and the people of lower domain had several restrictions and barred to use Sanskrit language in their conversation. Characters, other than Brahmanas and Kings in the dramas of Kalidasa are live example as Kabir converse in Prakrit language. Gradually these local languages became more popular which gave rise to a new language during 10th to 11th century $\mathrm{AD}$ due to intermingling of traditional as well as of foreign languages.

Beginning from the early mid 11thtoMid 14thcentury, the tremors of expanding Islamic culture's presence began to be felt on almost in whole of India ${ }^{1}$. Until then the northern and western parts of India were wrought in political instability, cultural insecurity and the terror of the advent of Islam. The inception of devout movement and the onslaught of Islam were curiously instantaneous in the whole of India (except South India) by this time. It would be wrong to assume that Kabir flourished as counter-movements. In fact, India became the stimulating meeting point of the two rebel groups i.e. Sufis being the rebel saint-poets against orthodox Islam, and Hindu saints placed similarly vis-à-vis the Brahmin orthodoxy as a mark of retaliation, reform movements were started through medieval Hindi poetry of the said period which were based on ethical practices.

It might be justified to point out that the devotion movement was long known in the South India as some of the scholars opine. The idea of preaching devotion through hymns and stories was traditionally done by the Alvars and the Nayannars of the Tamil devotional cult in southern part of India butIt was Ramananda who introduced egalitarian reforms in Vedic ideology and Kabir were readily accepted by his disciples who from lower castes and communities (shudras and atishudras (The fourth category of Hindu Hierarchical domain) whom he called 'harijans', (the people of lord), thus ruling out and dismissing the sanctity of caste from the very beginning. He brought about reconciliation between the Vedic and the folk culture, between theistic interpretations of Vedanta and Bhakti, and between the social divisions based on caste and the sectarian orientation of devotion. He introduced the cult of power Supreme worship in north, and thus gave rise to two schools of religious thought, one conservative and the other radical. Tulsidas, Soordas Meera etc can be considered as conservative and Kabir, Nanak, Ravidas, Dadu, Dyal, Peepa etc. can be taken in the category of radicals in this context.

The entire poetry of Kabir, having socio-culture influence from above mentioned Sanskrit texts and philosophical schools and initiation of Ramananda, has revealed the importunate of a sensitive mind which guides everyone to aim at higher pedestals in life, to which Prof. Naamvar Singh has referred to in his book titled "Doosari Parampara ke Khoj" (discovery of Second tradition).

To kabir, the philosophy of life begins from "Aatmaavadrashtavya, shrotriya, nidhidhyasitvya" as mentioned in the canto 4 of Brihadaranyaka Upanishad (Chapter 2 Brahman 45). He understood that the futility of action being made in the name of Yajna mindlessly. He not only criticizes every action thus performed by all of the factions of the then Indian society but asks every on to concentrate on the self and consider this ultimate reality and sole motto of the life since actions performed for the sake of rituals do not yield emancipation which is the ultimate goal of Human life. Thus, he cautions everyone to perform action with understanding that could yield a way of everlasting contentment and joy.

Some commentators believe that the philosophy of Kabir is a syncretism amalgamation of Hinduism and Islam, but scholars widely declare that this is false and a misunderstanding of Kabir. He adopted their terminologies and various concepts, but vigorously criticized them both as their practices could not pave the way of harmony for entire humanity. He pressed upon the need of harmony which could pave the way for everlasting happiness to everyone. For him, any holy book had no meaning if it could not paved the way of glee to everyone, as stated in Kabir Granthavali which is as follows: 
Reading book after book the whole world died, and none ever became learned!

(Kabir Granthavali, XXXIII.3, Translated by Charlotte Vaudeville)

Kabir rejected the double standards and injudicious rituals evident in all of the religious practices of his day, including those prevalent in Islam and Hinduism of his times. His words in this context can be quoted here in this context which are as follows

Saints I've seen both ways.

Hindus and Muslims don't want discipline, Kabir want tasty food.

The Hindu keeps the eleventh-day fast, eating chestnuts and milk.

He curbs his grain but not his brain, and breaks his fast with meat.

The Turk [Muslim] prays daily, fasts once a year, and crows "God!, God!" like a cock.

What heaven is reserved for people who kill chickens in the dark?

Instead of kindness and compassion, Kabir've cast out all desire.

One kills with a chop, one lets the blood drop, in both houses burns the same fire.

Turks and Hindus have one way, the guru's made it clear. Don't say Ram, don't say Khuda [Allah], so says Kabir.

(Kabir, Śabda 10, Translated by Linda Hess and Shukdeo Singh)

The notable aspects of moral discipline of Kabir can be divided into two major sections: i.e.

1. Personal Ethics of Kabir.

2. Social Ethics of Kabir

\subsection{Personal Ethics of Kabir}

It, firstly be made clear, that all of kabir is an aficionada of Power Supreme in the formlessness and thus, he asks the validity and utility of futile rituals being made in the name of Power Supreme in a un-daunting manner. His questions are simple yet have a depth of realization. To him, there is only one controlling power. The idea although has been taken from Upanishads yet the expression of thought has a different manner. Kabir, for instance, considers the Power Supreme in a inimitable manner and provides us the simile of great banyan tree which is upside down. The idea behind quoting it that Kabir tried to perceive uniformity in all of the human being.

Kabir, by way of his bards, has emphasized on the concept of oneness of God which could be achieved only through devotion. He does not discriminate between sectarian practices and religions. To him, everybody has an equal right to attain the Grace Divine. To attain his grace, Kabir think that best Caste, Valor, Time are insignificant10. According to him the path to realize the Supreme power lies in complete righteous conduct accompanied with complete surrender and not in any kind of rituals. He, thus, condemns the rituals and sacrifices being made in the name of Power supreme. For example, Kabir not only raises his personal speculation and doubts on the futile practices being made by everyone in the name of god without giving a second thought or curbing mind ${ }^{2}$. To him, meaning of devotion is complete surrender to The Power Supreme ${ }^{3}$ just like kitten principle of life . He, in order to achieve it, compassionately talks about universal love through his poetry. To him, discrimination between the entire humanity leads to sin. Kabir often opines when the power Supreme has created a single great human creed, in such a situation differentiating between races is meaningless. That is why henot only challenges the authenticity of Brahminhood but raises his certain doubts about it. Eventually, he is up against the discrimination which was being made in the name of caste, color and creed.

It might not be out of context to mention that their devotion is triggered by universal appeal of veneration and reverence for the Power Supreme which is ultimate Consciousness of self and every one, as to them, the Power Supreme and Inner consciousness is one and the same thing. Kabir are able to perceive the Ultimate power at every place. Kabir do not go to places of worship as it is not mandatory for them. Neither Kabir favor and carry out any rituals. Kabir understand that the veneration and reverence to the Power Supreme are the essence of good deed performed through mind and speech [11] as Kabir comprehend that that the rituals performed without any understanding do not pave the way for everlasting blissful existence.

Humility of Kabir can be noted from his famous verse when he says

\section{Bura Jo Dekhan Main Chala, Bura Naa Milya Koye Jo Munn Khoja Apnaa, To Mujhse Bura Naa Koye}

He searched and compared the malevolence in the people and himself, he could not find wickedness in the people but when he compared himself with the society none was worse than himself. Eventually, we find a comparative statement given by Kabir in the matter of character and opine that the ego problems of kabir are much grave than those of people of both of the religions. If we try and understand kabir is asking everyone renounce attitude problem as he understands the basic fact that these vices cannot pave the way of eternal happiness for the humanity and vice like ego, greed, etc must be kept at bay.

Kabir does not hamper after any worldly riches neither he is looking for worldly pleasure. One of the prominent couplet of kabir is worth quoting here in this context where

2Saat Sant Shikar ISBN 81-7028-870-3

3Saat Sant Shikar ISBN 81-7028-870-3 P. 28 \& 49 
He is seen as a contented soul and he prays the lord supreme to grant him satisfactory means which could be enough for him along with his family and other gentle stoics.

Sayeen Itna Deejiye, Ja Mein Kutumb Samaye Main Bhi Bhookha Na Rahun, Sadhu Na Bhookha Jaye

We can appreciate the fact that Kabir is not influenced with the worldly riches since he is an onlooker on the path of self-control. He is willing for renunciation of worldly riches because he has realized the basic fact that the worldly riches cannot pave the way of everlasting happiness rather Kabir are create hurdles in the path of true happiness. He presses upon meditation and self-control because it is the only means for the ultimate goal of human life and he himself states the condition of his mind by saying

Kabir Man Nirmal Bhaya, Jaise Ganga Neer Pache Pache Har Phire, Kahat Kabir Kabir

Mind of kabir has been detoxified with penance and self-control which is pious like the water of River Ganges. Now the Supreme self is after him and it is taking care of kabir himself.

\subsection{Social Ethics of Kabir}

It is a well-known fact that the healthy individuals form the healthy society and healthy society can carve the healthy individuals. Keeping this in view, the medieval devout have always made specific recommendations in the form of personal ethics that may be benevolent and beneficial for the human society at large ${ }^{[12]}$. It is worth to point out, at this juncture, that the medieval poets repeatedly emphasize on life's great virtues like chastity, desire-less actions, faith, etc. Kabir make every one aware of the fact that the human birth is rarest of rare thus Kabir emphasize on the righteous deed and ask every one about the positive-ness in his or her character ${ }^{4}$ thereby setting the moral guideline to every person not to yearn for money or earthly riches. It may point out that Kabir asks everyone to denunciate his or her personal voracious \& insatiable desire/longing for worldly riches so as to make this world a better and peaceful living place. The idea of Kabir is somewhat similar to the ideas propagated by ancient Indian literature

It must be said that the poets of said period are very conscious about the fact that the path to enduring happiness does not lie in the path of senses and their aim of life is to realize the true inner self. Kabir, in order to achieve success in their endeavor, denounce the physical pleasure and try to

4Seelvant sab se bada sab ratnananke khan Teewnlikkesampadarahiseel main aan: Kabir concentrate on their true inner-self which Kabir consider a fragment of the Supreme Soul. Charlotte Vaudeville opines that the philosophy of Kabir and other saints of the Bhakti movement is the seeking of the Absolute. The notion of this Absolute is nirguna of Kabir is in accordance with the Upanishadic concept of the Brahman-Atman and the monistic interpretation of the Vedantic tradition which denies distinction of any kind between the soul and God, and urges man to recognize the true essence of self which is of true divine nature. It must be pointed out that many other saint like kabir have been pressing up the same came concept as of Kabir and according the this particular though process may be called as "union with God" rather than the concept of "merging into God, or Oneness in all beings"

Kabir, surprisingly, is very conscious about his spiritual progression when he makes the onlooker aware and guides him to become man of righteous conduct. Kabir is also aware of the delusionary power and term it as Maya and ask everyone to be aware of this Maya which makes everyone deviate from the noble path of humanity. He understands that the actions motivated by greed, hatred and delusion have a tendency to drive away from reality those who follow them ${ }^{[13]}$. Actions carried out with better motivations, but still infused with a sense of self, tend to produce rebirth. Vast numbers of sentient beings are trapped in this cycle, continually wandering from one realm to another, unable to escape and forced to experience the forms of suffering that exist in each realm ${ }^{5}$. Kabir understands this very secret of action, propagated by the ancient Indian Wisdom and make everyone aware of this very fact. To him, the human realm is particularly fortunate, because it is the only single threshold in entire universe which can lead everyone on the path of self-emancipation. That is why Kabir ask everyone to curb his or her senses in a positive direction so as to make this earth a better place for living. He understands that the human mind is the root cause of lust, greed and likewise every evil. Thus, He believes in controlling his mind in a positive sense and he curbs it in appositive direction and thus isable to lead a cheerful life. He is aware of the fact that the meaning of their blissful existence lies in co-operation of all animate and inanimate being and not in ruthless competition. We may come across the reference of Yama Nachiketa dialogues in Kathoupanish where Yama elucidates the theory of action by saying "Living in the midst of Ignorance and considering themselves intelligent and enlightened, the senseless people go round and round, following the crooked courses, just like the blind led by the blind"(KathoUpanishad1.ii.5). He probably understand that life has multiple choice for harmony and thus he asks very one to discriminate between the right and wrong

5 KathoUpanishad II.2.2 \& cf Ishopanishad 1 
choice because knowledge and ignorance are widely apart and they have divergent courses. (KathoUpanishad1.ii.2 )

In Bijak, Kabir ridicules the practice of praying to various incarnations ${ }^{6}$. Kabir urges people, who carry out their routine religious practices, to look within and consider all human beings as manifestation of God's living forms ${ }^{7}$. In other words he renounces all of those futile practice and presses upon the practices which could establish his or her identity with the power supreme. His saying in this regard is quotable when says:

If God be within the mosque, then to whom does this world belong?

If Ram be within the image which you find upon your pilgrimage,

then who is there to know what happens without?

Hari is in the East, Allah is in the West.

Look within your heart, for there you will find both Karim and Ram;

All the men and women of the world are His living forms.

Kabir is the child of Allah and of Ram: He is my Guru, He is my Pir.

( Kabir, III.2, Translated by Rabindranath Tagore)

Kabir probably also comprehends that the means for the attainment of other world does not become revealed to the non-discriminating man who blunders, being fooled by lure of wealth (KathoUpanishad1.ii.6).Thus he implores everyone to be of righteous conduct/behavior as the superior conduct is far more important than a person with earthen riches. To him peace of mind occupies the first place in conduct. He opines that the riches and wealth becomes meaningless for the one who conducts himself in the righteous way. It will justified to way propagated by Kabir is a process of self-realization, is a process of becoming from being in which one has to uplift himself by means of these very basic qualities of life for self-liberation and this only can be done by mean of adopting these great virtues of life.

It will not be amiss to mention that Ancient Indian wisdom indicates that the actions are of two types but also suggest the type of action which are to be performed by the person by saying that "Accordingly one acts, accordingly one conducts himself so does he become. One becomes virtuous by performing good deeds and the other becomes evil by performing this unworthy deeds",[13] Further the ancient Indian Wisdom mentions that "But people say a person is made of desires only what actions he had performed that he produced for himself". The

6 Hess, Linda; Shukdev Singh (2002). The Bijak of Kabir. Oxford University Press. ISBN 978-8120802162.

7 Wendy Doniger (2010), The Hindus: An Alternative History, Oxford University Press, page 484
Medieval Hindi poets not only understand these basic notions about the conduct but, on the contrary ask everyone to be considerate about the conduct ${ }^{[14]}$.

Kabir talks of universal love in unbiased manner through his poetry and asks everyone to comprehend it through higher understanding. Kabir, for example, understands that the Power Supreme is his originator and prays him to pardon his evil deed just like a mother pardons all evil deeds of her son ${ }^{[15]}$. He asks everyone to abstain from the company who are devotion-less as Kabir is neither paving a way of blissful living for self nor for any other.

$\mathrm{Kabir}^{8}$ does not admire gaining wealth and riches of the world but is desirous of spiritual progression through controlled conduct and thus asks everyone to mend his conduct in positive manner as the conduct is far more important than anything in this immanent world. It must be pointed out that one cannot attain satisfaction in life if one's conduct is triggered by the lust, greed or one cannot be satisfied by attaining the material progress. One may be very rich but cannot attain the psychological progression at all. We must comprehend the fact that mental calmness can be attained only through self-control ${ }^{[16]}$. These devouts are definitely the trekker on the path of self-emancipation as their point of concentration lies in the inner self and not in the riches of the outside world. Almost every poet of medieval times repeatedly stress upon the great virtues of non-greediness which is the pre-requisite for the path of ever-lasting happiness thereby putting constraint on the self in positive sense. The poetry of Kabir categorically announces that "A person with the righteous conduct is far better than the a person with mortal riches as personal righteous conduct is better than yearning for wealth"[17]. Medieval poets understand the dictum of The Kathopanishad which elucidates the fact that the indomitable thirst for the wealth cannot be quenched by any means "Not with the wealth is a man to be satisfied ever" which has the deeper psychological implication. Kabir understood that the thirst for wealth is a barring substance in the path of self-progression. It is for this reason that Kabir talk of self-control and Kabir, categorically, is quotable in this context when he prays to the Power Supreme to grant him the assets which are sufficient for his guest, family and self. Kabir ${ }^{[18]}$, Nanak, Ravidass etc. have all their praises for the elevated conduct.

As earlier submission, that these bunch of poets are devout and it will not be amiss to mention that Kabir is much indebted to their Mentors who led them on the path of self-emancipation and have all of the praises for him as the Guru altered their life in a positive manner and express their heart-full gratitude to their mentors ${ }^{[19]}$.

8 KathoUpanishadI.ii.5 \& Ishoupanishad 3 
We find an interesting verse in Mahabharat: the epic of Ancient Indian literature which clarifies it's stand on truth. According to this verse, truth speaking is better, truth with advantage is still better. But form of truth which is told with compassion and by which everybody is benefitted, is the best form of truth. Keeping this very concept in mind, we find that these poets excel their own masters in the sense that Kabir believe in that form of truth which is unconditional and which is based on their self-experience. The point worth appreciating of Kabir is that he does not end his learning process with what Kabir have told by their spiritual masters but he makes further advancement. To him, the best form of truth is which is in consonance with the unbiased self-experience.

\section{Concluding Remarks}

Although the spirit of devotion pervaded whole of India and found vivid and beautiful expression in the poetry of the Kabir, no matter what religious faith he believed in and their literary compositions, rendered into offerings etc. united the people, as nothing else could have done at that time yet it is considered as religious poetry which is prevalent in the contemporary Indian society. It goes without saying that it has stimulated the development of regional languages and Indian civilization from the root itself.

We must yield to the fact that the entire humanity is on the brink of catastrophe as our point of consideration has shifted from humanism to monetary and material gains. Our artificial physical needs have led us in the cycle of never ending needs. Our position is like that of a kitten that is chasing its tail and going in to cycles endlessly. The poetry of Kabir is still relevant in the modern perspective as it is an expression of substance and provides us a wiser vision of life. It has a capability to drive everyone to concentrate and improve his inner-self so as to make his life a better and blissful living experience. Need of the hour is that the poetry of Kabir be understood in the right perspective.

\section{REFERENCES}

[1] Paul, Richard; Elder, Linda (2006). The Miniature Guide to Understanding the Foundations of Ethical Reasoning. United States: Foundation for Critical Thinking Free Press. p. np. ISBN0-944583-17-2.

[2] John Deigh in Robert Audi (ed), The Cambridge Dictionary of Philosophy, 1995.

[3] Oxford Advance learner Dictionary P.427.

[4] Kidder, Lobaton (2003). How Good People Make Tough Choices Rev Ed: Resolving the Dilemmas of Ethical Living. New York: Harper Collins. p. 63. ISBN0-688-17590-2.
[5] "What is ethics?".BBC. Archived from the original on October 28, 2013. Retrieved July 22, 2014.

[6] http://www.iep.utm.edu/non-cogn/

[7] Miller, C. (2009). The Conditions of Moral Realism. The Journal of Philosophical Research, 34, 123-155.

[8] Cavalier, Robert. "Meta-ethics, Normative Ethics, and Applied Ethics". Online Guide to Ethics and Moral Philosophy. Archived from the original on November 12, 2013. Retrieved February 26, 2014.

[9] William S. Sahakian; Mabel Lewis Sahakian (1966). Ideas of the Great Philosophers. Barnes \& Noble. ISBN978-1-56619-271-2.

[10] Saat Sant Shikar ISBN 81-7028-870-3 P.103

[11] Brihad. IV.4.5

[12] Guru Milya Ramaanand: Ed. Kosalendra Das

[13] Saat Sant Shikar ISBN 81-7028-870-3

[14] Saat Sant Shikar ISBN 81-7028-870-3 P. 28 \& 49

[15] Saat Sant Shikar ISBN 81-7028-870-3 P. 48

[16] Santo Ki Bani by Charan Singh : RadhaSoamiSatsangP.187 Verse 27

[17] Santo Ki Bani by Charan Singh : Radha Soami Satsang, P. 125 Verse 42

[18] Kabir by Hazari Prasad Dwevidi

[19] Santo Ki Bani by Charan Singh : RadhaSoamiSatsangP.111 Verse 1-4 